\section{OPEN ACCESS}

Edited by:

Jorg Hermann Fritz,

McGill University, Canada

Reviewed by:

Eui-Cheol Shin,

Korea Advanced Institute of Science \& Technology, South Korea Philippe Georgel, University of Strasbourg, France

${ }^{*}$ Correspondence: Naglaa H. Shoukry naglaa.shoukry@umontreal.ca

Specialty section:

This article was submitted to Molecular Innate Immunity, a section of the journal

Frontiers in Immunology

Received: 01 November 2016 Accepted: 08 December 2016 Published: 23 December 2016

Citation: Boisvert M and Shoukry NH (2016) Type III Interferons in Hepatitis C Virus Infection.

Front. Immunol. 7:628. doi: 10.3389/fimmu.2016.00628

\title{
Type III Interferons in Hepatitis C Virus Infection
}

\author{
Maude Boisvert ${ }^{1}$ and Naglaa H. Shoukry ${ }^{1,2 *}$ \\ ${ }^{1}$ Centre de Recherche du Centre Hospitalier de l'Université de Montréal (CRCHUM), Montréal, QC, Canada, ${ }^{2}$ Département \\ de médecine, Université de Montréal, Montréal, QC, Canada
}

The interferon (IFN)- $\lambda$ family of type III cytokines includes the closely related interleukin (IL)-28A (IFN- $\lambda 2$ ), IL-28B (IFN- $\lambda 3$ ), and IL-29 (IFN- $\lambda 1$ ). They signal through the Janus kinases (JAK)-signal transducers and activators of transcription pathway and promote an antiviral state by the induction of expression of several interferon-stimulated genes (ISGs). Contrary to type I IFNs, the effect of IFN- $\lambda$ cytokines is largely limited to epithelial cells due to the restricted pattern of expression of their specific receptor. Several genomewide association studies have established a strong correlation between polymorphism in the region of IL-28B gene (encoding for IFN- $\lambda 3$ ) and both spontaneous and therapeutic IFN-mediated clearance of hepatitis $\mathrm{C}$ virus ( $\mathrm{HCV}$ ) infection, but the mechanism(s) underlying this enhanced viral clearance are not fully understood. IFN- $\lambda 3$ directly inhibits HCV replication, and in vitro studies suggest that polymorphism in the IFN- $\lambda 3$ and its recently identified overlapping IFN- $\lambda 4$ govern the pattern of ISGs induced upon HCV infection of hepatocytes. IFN- $\lambda$ can also be produced by dendritic cells, and apart from its antiviral action on hepatocytes, it can regulate the inflammatory response of monocytes/macrophages, thus acting at the interface between innate and adaptive immunity. Here, we review the current state of knowledge about the role of IFN- $\lambda$ cytokines in mediating and regulating the immune response during acute and chronic HCV infections.

\section{Keywords: hepatitis C, IFN- $\lambda 3$, IFN- $\lambda 4$, liver, SNP, HCV clearance, SVR}

\section{INTRODUCTION}

The interferon (IFN)- $\lambda$ family of cytokines was first described in 2003 by two independent groups (1, 2). By using computational analysis of unknown genes potentially corresponding to cytokines that were related to interleukin (IL)-10 and type I IFNs, Sheppard et al. identified three new cytokines, IL-28A, IL-28B, and IL-29 (2). Expression of these three cytokines could be induced in peripheral blood mononuclear cells (PBMCs) and other cell types upon poly I:C stimulation or viral infection. Furthermore, these cytokines demonstrated antiviral activity and were shown to bind to a new receptor, IL-28R $\alpha$, that forms a heterodimer with IL-10R2. Around the same time, Kotenko et al. also identified three new genes related to the IFN type I and IL-10 families (1). The new cytokines were named IFN- $\lambda 1$, IFN- $\lambda 2$, and IFN- $\lambda 3$ (equivalent to IL-29, IL-28A, and IL-28B, respectively). The newly described cytokines were shown to bind to a new receptor complex composed of IFN- $\lambda$ R 1 (equivalent to IL-28R $\alpha$ ) and the IL-10R2, signal through the Janus kinases-signal transducers and activators of transcription (Jak-STAT) pathway, and exhibit antiviral activities via the induction of interferon-stimulated genes (ISGs) and upregulation of major histocompatibility complex (MHC) class I. In 2013, a dinucleotide frameshift variant rs368234815 (previously termed ss469415590) 
(TT or $\Delta \mathrm{G}$ ) was identified in the IFN- $\lambda$ region. This frameshift variant was shown to create a novel gene, IFNL4, encoding the IFN- $\lambda 4$ protein (3). This new protein was related to IFN- $\lambda 3(29.1 \%$ identity and $40.8 \%$ similarity between both proteins). Expression of IFN- $\lambda 4$ activated the Jak-STAT pathway and resulted in the expression of ISGs (3). In this article, we will use the nomenclature of IFN- $\lambda$ genes, protein, and polymorphisms according to the Human Genome Organization Gene Nomenclature Committee. Alternative names for IFN- $\lambda$ genes and proteins (including IFN- $\lambda$ specific receptor) are listed in Table $\mathbf{1}$.

\section{TISSUE TROPISM OF TYPE I VERSUS TYPE III IFNs}

Type I and type III IFNs are related and may act in parallel via the same pathways. Type I IFNs (IFN $\alpha / \beta$ ) can act on multiple cell types and tissues because their specific receptors (IFNAR1 and IFNAR2) are ubiquitously expressed. In contrast, IFN- $\lambda$ R1 expression is rather restricted and as such it affects a much more limited set of cells and exhibits reduced side effects (4). IFN$\lambda \mathrm{R} 1$ is mostly expressed by cells of epithelial origin including hepatocytes $(5,6)$. However, its expression on hematopoietic cells remains controversial. This issue is discussed in more detail below, but it is generally believed that the main immune cells expressing IFN- $\lambda$ R 1 are dendritic cells (DCs) $(4,7,8)$. Most studies assessed the expression of IFN- $\lambda \mathrm{R} 1$ by polymerase chain reaction (PCR), evaluating the mRNA level, which might not accurately reflect expression of the protein on cell surface. It was demonstrated that immune cells [B cells, T cells, and natural killer (NK) cells] express mostly a shorter splice variant of IFN- $\lambda$ R 1 that can be secreted (9). This secreted form could bind IFN- $\lambda$ with moderate affinity and inhibit its effects. This could explain at least in part why immune cells express IFN- $\lambda$ R 1 mRNA but lack responsiveness to IFN- $\lambda$ treatment.

\section{ASSOCIATION OF TYPE III IFN POLYMORPHISMS WITH HCV SPONTANEOUS CLEARANCE AND RESPONSE TO IFN THERAPY}

Hepatitis C virus (HCV) infection is a global health problem. Only $25 \%$ of individuals acutely infected with HCV are able to eliminate the virus spontaneously, while the majority $(\sim 75 \%)$ develops persistent infection and chronic liver disease including fibrosis, cirrhosis, and liver cancer (10). Until 2011, the only

TABLE 1 | Type III IFN genes and proteins.

\begin{tabular}{lllll}
\hline & Gene & $\begin{array}{l}\text { Alternate gene } \\
\text { names }\end{array}$ & Protein & $\begin{array}{l}\text { Alternate protein } \\
\text { names }\end{array}$ \\
\hline Receptor & IFNLR1 & $\begin{array}{l}\text { IL-28RA, IL-28R1, } \\
\text { IFNLR }\end{array}$ & IFN- $\lambda R 1$ & $\begin{array}{l}\text { IL-28RA, IL-28R } \alpha, \\
\text { IL-28R1 }\end{array}$ \\
Cytokines & IFNL1 & IL-29 & IFN- $\lambda 1$ & IL-29 \\
& IFNL2 & IL-28A & IFN- $\lambda 2$ & IL-28A \\
& IFNL3 & IL-28B & IFN- $\lambda 3$ & IL-28B \\
& IFNL4 & - & IFN- $\lambda 4$ & -
\end{tabular}

available treatment for $\mathrm{HCV}$ was a combination of ribavirin and pegylated IFN- $\alpha$ (11). This non-specific treatment was modestly effective, especially in individuals infected with genotype 1, resulting in $\sim 50 \%$ sustained virological response (SVR) rate defined as undetectable viral load 24 weeks following the end of treatment (12). Furthermore, the course of treatment was long (48 weeks) and associated with multiple side effects, thus significantly impacting the quality of life of the patients (13). Factors associated with higher odds of spontaneous resolution or response to IFN therapy include virus genotype, gender, and ethnicity, suggesting that genetic factors are key determinants of viral clearance $(14,15)$. Individuals of European ethnicities were more likely to achieve SVR compared to individuals of African ancestry $(14,16)$. These differences accompanied by the difficulties and side effects associated with IFN treatment prompted research into genetic factors that can predict SVR. Several genome-wide association studies demonstrated a link between single-nucleotide polymorphisms (SNP) near the IFNL3 gene encoding IFN- $\lambda 3$ and $\mathrm{HCV}$ infection outcome and response to treatment. These major polymorphisms are listed in Table 2 . Ge et al. demonstrated that the IFN- $\lambda 3$ rs 12979860 SNP predicted the response to IFN treatment in an American cohort composed of multiple ethnicities infected with HCV genotype 1 (17). The favorable allele (CC genotype) was not only overrepresented in the treatment responder group but was also more prevalent in the European population compared to the African population where the unfavorable TT genotype was more prevalent. Moreover, the IFN- $\lambda 3$ rs12979860 genotype was a better predictor of treatment outcome than ethnicity, since African Americans with the CC genotype were more likely to achieve SVR than the European American bearing the TT genotype (17). That study also demonstrated that the CC genotype was associated with higher baseline viral loads in all groups tested. Two other studies confirmed the same association with polymorphism in the IFN- $\lambda 3$ region in Australian (18) and Japanese cohorts (19) and identified an additional SNP (rs8099917). This SNP was associated with HCV genotype 1 treatment response in the Australian cohort and confirmed with other cohorts (18). This study also used quantitative reverse transcription PCR to demonstrate that healthy individuals carrying the favorable allele (TT) expressed higher levels of IFN- $\lambda 2$ and IFN- $\lambda 3$ transcripts in peripheral blood. In the Japanese cohort, both SNPs (rs12979860 and rs8099917) were associated with treatment response (19).

The favorable rs12979860 CC genotype was also associated with spontaneous clearance in untreated individuals from six different cohorts (20). In this study, Thomas et al. also observed

\begin{tabular}{|c|c|c|c|c|}
\hline SNP & $\begin{array}{l}\text { Common } \\
\text { name }\end{array}$ & $\begin{array}{l}\text { Alternative } \\
\text { names }\end{array}$ & $\begin{array}{l}\text { Favorable } \\
\text { allele }\end{array}$ & $\begin{array}{l}\text { Unfavorable } \\
\text { allele }\end{array}$ \\
\hline rs12979860 & IFN- $\lambda 3$ & $\begin{array}{l}\text { IL-28B } \\
\text { IFNL4 rs12979860 }\end{array}$ & $\mathrm{CC}$ & $\pi$ \\
\hline rs8099917 & IFN- $\lambda 3$ & IL-28B & $\pi$ & GG \\
\hline rs368234815 & $\mathrm{IFN}-\lambda 4$ & ss469415590 & $\pi$ & $\Delta G$ \\
\hline rs117648444 & $\begin{array}{l}\text { IFN- } \lambda 4- \\
\text { P70S }\end{array}$ & & $\begin{array}{l}\text { AA } \\
(\mathrm{IFN}-\lambda 4-\mathrm{S} 70)\end{array}$ & $\begin{array}{l}\text { GG } \\
(\mathrm{IFN}-\lambda 4-\mathrm{P} 70)\end{array}$ \\
\hline
\end{tabular}


that the $\mathrm{C}$ allele was more represented in Europeans compared to African individuals. More importantly, they demonstrated that the $\mathrm{C}$ allele was associated with spontaneous resolution of $\mathrm{HCV}$ infection in both ethnic groups. Moreover, the protective effect appeared to be recessive, since there was no difference between heterozygous individuals bearing the CT genotype and homozygous individuals bearing the TT genotype. This study also genotyped $>2,000$ individuals worldwide and demonstrated that the $\mathrm{C}$ allele was most prevalent in East Asia, whereas the $\mathrm{T}$ allele was most prevalent in Africa and an intermediate pattern with both alleles was observed in Europe. Similar results were obtained by Rauch et al. who sequenced the IFN- $\lambda 3$ rs8099917 SNP and showed association of the unfavorable allele with establishment of a chronic infection and treatment failure in HCV monoinfected and HCV/HIV coinfected individuals (21). Finally, the IFN- $\lambda 3$ rs12979860 SNP was also associated with spontaneous clearance and jaundice in a single-source cohort (22). The German anti-D cohort consists of 2,867 women who were exposed to HCV genotype $1 \mathrm{~b}$ after treatment with anti-D immunoglobulin. Fifty-two percent of infected women achieved spontaneous clearance. This cohort enabled the evaluation of the role of IFN- $\lambda 3$ polymorphism in spontaneous clearance without the confounding effect of virus genetics. In this cohort, it was possible to analyze genetic factors associated with spontaneous clearance in 190 women. Results demonstrated that spontaneous clearance was strongly associated with the IL-28B/IFN- $\lambda 3$ genotype (22). The highest rate of clearance was observed in women homozygous for the favorable $\mathrm{C}$ allele (CC, $64.2 \%$ clearance), the lowest rate of clearance was observed in women homozygous for the unfavorable T allele (TT, 6.1\% clearance), and intermediate levels of clearance were observed in heterozygous women (CT, $24.4 \%$ clearance) (22). IFN- $\lambda 3$ favorable genotype was also associated with clearance upon reinfection in high-risk people who inject drugs (23).

In 2013, a new dinucleotide polymorphism rs368234815 (previously termed ss469415590) located near the IFNL3 gene was identified, and the variants TT or $\Delta \mathrm{G}$ were associated with a frame shift resulting in either production of a new protein, IFN$\lambda 4,(\Delta \mathrm{G})$ or absence of the protein due to the introduction of a frameshift creating an early stop codon (TT) $(3,24)$. This new polymorphism was in high linkage disequilibrium with the IFN$\lambda 3$ rs12979860 polymorphism and was found to be a stronger predictor of $\mathrm{HCV}$ spontaneous resolution and treatment outcome of chronic $\operatorname{HCV}(3,25,26)$. Another group reported association of the TT/ $\Delta \mathrm{G}$ polymorphism with $\mathrm{HCV}$ treatment outcome in a large European cohort (27). Given that the IFN- $\lambda 3$ rs 12979860 was located within the newly discovered IFN- $\lambda 4$ region, it was suggested to change its nomenclature to IFN- $\lambda 4$ rs12979860 (24).

\section{MECHANISMS UNDERLYING THE ROLE OF IFN- $\lambda$ POLYMORPHISMS IN HCV CLEARANCE}

The exact mechanisms underlying the role of IFN- $\lambda$ polymorphisms in HCV clearance are not well understood. It was proposed that such polymorphisms may influence the expression of
IFN- $\lambda$ cytokines during $\mathrm{HCV}$ infection and their downstream effects on expression of ISGs and innate and adaptive immune cells. Although it was demonstrated early on that IFN- $\lambda$ SNPs may influence expression of the IFN- $\lambda$ transcripts in PBMCs (18), data evaluating the circulating levels of IFN- $\lambda$ cytokines during acute and chronic HCV were inconclusive. Data from the chimp model of HCV infection demonstrated that type III IFNs were strongly induced upon HCV infection at the gene and protein level and correlated with ISG expression and viral load (28). In humans, while some studies associated the favorable IFN- $\lambda 3$ CC allele with higher serum levels of IFN- $\lambda$ (29), others demonstrated the reverse correlation (7). One report also found no difference in serum levels of IFN- $\lambda$ between $\mathrm{HCV}$ treatment responders and non-responders (30). Our group has demonstrated that serum levels of IFN- $\lambda 3$ were highly variable, but were lower in individuals bearing the favorable IFN- $\lambda 3$ CC allele (31). Altogether, type III IFN genotyping has been, so far, a more accurate predictor for $\mathrm{HCV}$ infection or treatment outcome compared to the circulating levels of the cytokines.

How the expression of IFN- $\lambda 4$ would interfere with $\mathrm{HCV}$ clearance or treatment response is not fully understood. It was shown that the protein is only poorly secreted $(3,32)$. Nevertheless, the protein could interact with the same receptor as IFN- $\lambda 3$ (IFN- $\lambda$ R 1 and IL-10R2) and displayed similar levels of activation of ISGs and antiviral activity (32). It remains possible that IFN- $\lambda 4$ has other functions apart from activation of ISGs, perhaps through the interaction with an intracellular receptor. Both IFN- $\lambda 3$ and IFN- $\lambda 4$ polymorphisms were associated with the level of expression of the type I IFN receptor IFNAR1 in PMBCs (33). Individuals carrying both favorable alleles expressed the highest level of IFNAR1, while individuals bearing both unfavorable alleles exhibited lower levels. Treatment of PBMC with IFN- $\alpha$ confirmed that individuals with both favorable alleles and the highest IFNAR1 expression also exhibited the highest ISG induction.

Several early studies demonstrated a link between the liver expression levels of ISGs before IFN treatment initiation and treatment outcome (34-37). A higher level of expression of a set of ISGs and genes involved in IFN regulatory pathways (ISG15 and USP18) was observed in non-responder patients before treatment and predicted treatment outcome (34). Furthermore, the level of expression of several ISGs was shown to correlate with IFN- $\lambda$ genotypes, with the unfavorable alleles associated with higher hepatic levels of ISGs $(37,38)$. Unphosphorylated IFN-stimulated gene factor 3 (ISGF3) is induced by type III IFNs and sustains expression of USP18, a negative regulator of IFN signaling, resulting in unresponsiveness to IFN- $\alpha$ treatment (39). Comparison of levels of ISGs before and after treatment further demonstrated that the high basal expression levels in non-responders did not increase above pretreatment level, whereas there was a strong ISGs induction in the SVR group (40). This suggests that the baseline high ISG levels in non-responders render them unresponsive to further IFN stimulation upon therapy. Extending this hypothesis to explain why the expression of IFN- $\lambda 4$ would be detrimental for $\mathrm{HCV}$ infection and treatment outcome, patients expressing a less active variant of the IFN- $\lambda 4$ protein had better odds of achieving spontaneous clearance or SVR (41). This study demonstrated that 
the IFN- $\lambda 4$-S70 protein (SNP rs117648444) exhibited reduced ISG activation and antiviral activity in vitro. When comparing infection and treatment outcome in a large cohort, individuals bearing genetic variants resulting in no IFN- $\lambda 4$ production had the highest odds of clearance/SVR, followed by those expressing the IFN- $\lambda 4$-S70 impaired protein and finally those expressing the IFN- $\lambda 4$-P70 fully active protein had the lowest odds of achieving clearance/SVR.

On the basis of current knowledge, we can elaborate a model where during acute $\mathrm{HCV}$ infection, innate immune responses are induced in hepatocytes that trigger the production of type III cytokines that stimulate a variety of antiviral ISGs. In individuals carrying the favorable IFN- $\lambda 3$ rs $12979860 \mathrm{CC}$ and IFN- $\lambda 4$ rs368234815 TT alleles, production of IFN- $\lambda$ is controlled, and the induction of ISGs is more focused leading to an effective antiviral state and increased rate of spontaneous resolution of infection. In contrast, carriers of the unfavorable alleles exhibit stronger IFN- $\lambda$ production and a more diverse array of ISGs. This will also induce the expression of USP18, an inhibitor of the IFN signaling pathway, leading to an impaired antiviral state and to an increased propensity to develop chronic infection. This effect is not absolute, and some individuals carrying the favorable alleles will develop chronic infection. In chronically infected individuals carrying the favorable allele, basal levels of IFN- $\lambda$ and ISGs will be relatively low and treatment with IFN- $\alpha$ can induce a potent antiviral state leading to viral clearance or SVR. In individuals carrying the unfavorable allele, a high basal level of IFN- $\lambda$, ISGs, and USP18 will lead to a refractory state and unresponsiveness to the IFN- $\alpha$ treatment, and failure to respond to treatment (Figure 1).

\section{TYPE III IFNs AND INNATE IMMUNITY IN THE LIVER}

$\mathrm{HCV}$ is a hepatotropic infection and investigation of the early steps of viral replication, and the innate immune response is hindered by the difficulty to access the infected tissue, i.e., the liver. In vitro systems usually show low level of viral replication, and animal models to study the immune response are limited to chimpanzees that are no longer used in research. Thus, limited information is available about the activation of the innate immune response
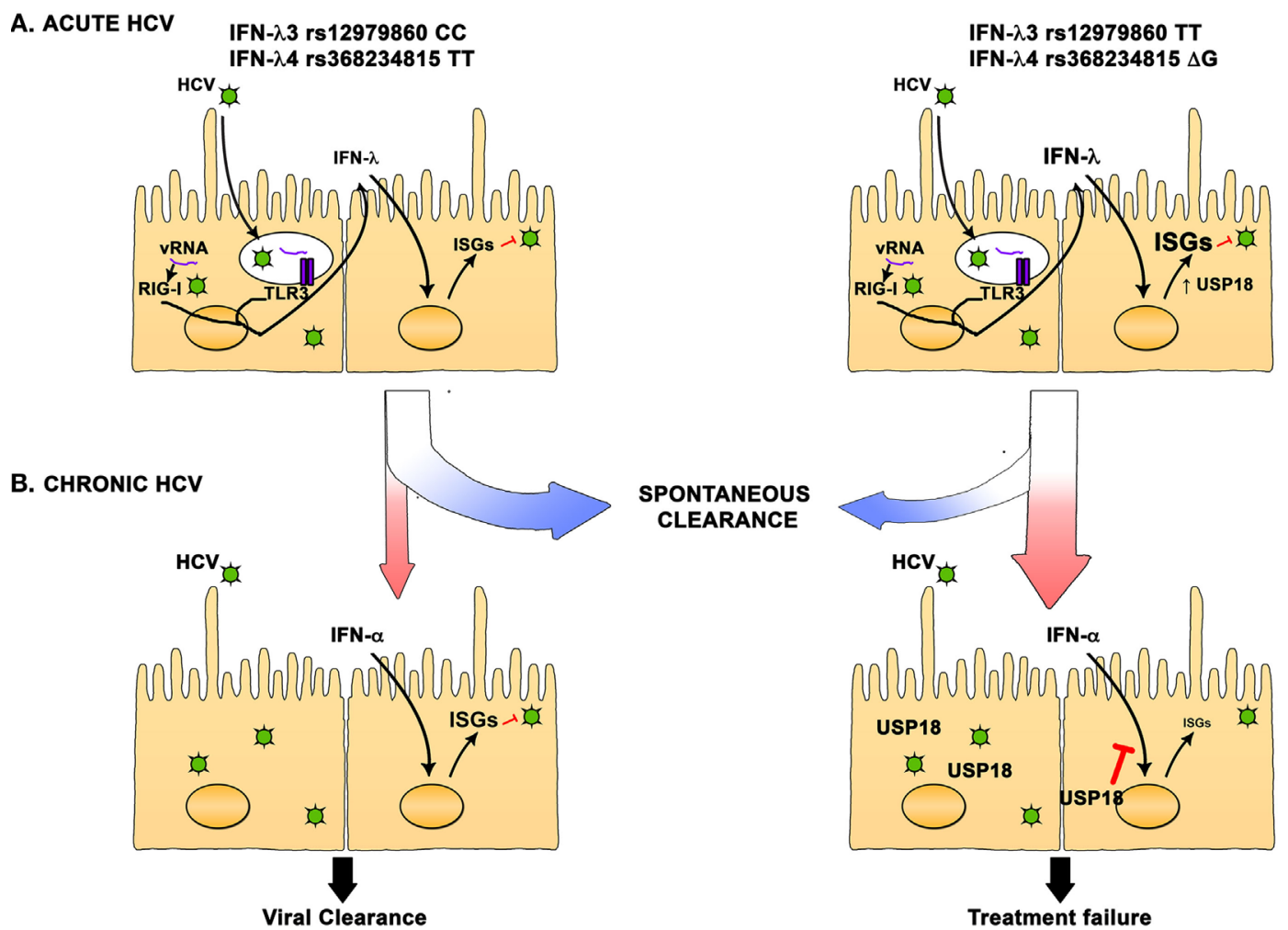

FIGURE 1 | Interferon (IFN)- $\lambda$ polymorphisms are associated with hepatitis C virus (HCV) spontaneous resolution and response to treatment. (A) In HCV acutely infected individuals, IFN- $\lambda 3$ rs 12979860 CC and IFN- $\lambda 4$ rs368234815 TT favorable alleles are strongly associated with spontaneous resolution. Hepatocyte infection triggers the production of IFN- $\lambda$ that then induce the expression of hundreds of interferon-stimulated genes (ISGs). In individuals carrying the favorable alleles, production of IFN- $\lambda$ is moderate, and the ISGs induction is more focused, leading to an effective antiviral state and increased rate of spontaneous resolution of infection. On the other hand, carriers of the unfavorable alleles exhibit stronger IFN- $\lambda$ production and a more diverse array of ISGs can be detected. This will also induce the expression of USP18, an inhibitor of the IFN signaling pathway, leading to an impaired antiviral state and an increased rate of chronic HCV infection. (B) In chronically infected individuals carrying the favorable allele, basal level of IFN- $\lambda$ and ISGs is relatively low and treatment with IFN- $\alpha$ can induce a potent antiviral state leading to viral clearance or SVR. In individuals carrying the unfavorable allele, a high basal level of IFN- $\lambda$, ISGs, and USP18 will lead to a refractory state and unresponsiveness to the IFN- $\alpha$ treatment and failure to clear the infection. 
in the liver of HCV-infected individuals during acute infection. Nevertheless, chimpanzee data have demonstrated strong induction of ISGs in the liver early after infection irrespective of the outcome toward resolution or chronicity $(42,43)$. Examining the kinetics of type I versus type III IFNs demonstrated that HCVinfected chimpanzees exhibited rapid induction of type III IFNs in the liver. This was associated with upregulation of ISGs but minimal induction of type I IFNs (44). Similarly, infection of primary human hepatocytes ( $\mathrm{PHHs}$ ) induced production of type III IFNs that were associated with induction of a distinct set of ISGs compared to type I IFNs $(44,45)$. Sheahan et al. used PHHs and laser capture microdissection to compare the transcriptional profile of HCV-infected hepatocytes to adjacent uninfected cells (46). They demonstrated that infected cells had a transcriptional profile dominated by innate immunity genes, including induction of IFN- $\lambda$ genes only in infected cells. Interestingly, when comparing gene expression from donors of different IFN- $\lambda$ genotypes, they demonstrated that even if a greater number of genes were induced in the unfavorable (TT) allele group, the response in the favorable allele group (CC) was more focused toward antiviral and cell death responses, and unsurprisingly, viral replication was more limited in donors bearing the favorable allele (46). Onabajo et al. also used an in vitro system of PHHs and hepatic cells and demonstrated that IFN- $\lambda 4$, while highly retained inside cells, is also secreted and induces strong ISGs response in surrounding cells, including the expression of IP-10 (47). However, IFN- $\lambda 4$ expression was associated with reduced proliferation and increased cell death (47). Ferraris et al. used $\mathrm{PHHs}$ of different IFN- $\lambda 3 / 4$ genotypes to investigate the mechanisms associated with HCV clearance (48). Treatment of $\mathrm{HCV}$-infected cells with either IFN- $\alpha$ or IFN- $\lambda 1$ decreased viral load only in cultures carrying the favorable IFN- $\lambda 3 / 4$ alleles (48). They also showed that, in both PHHs and liver biopsies of HCVinfected subjects, IFN- $\lambda 1$, IFN- $\lambda 3$, and ISGs production were higher in carriers of the unfavorable allele. Silencing of IFN- $\lambda 1$ in unfavorable allele context restored IFN- $\alpha$ antiviral activity, suggesting that the high basal IFN- $\lambda$ and ISG expression blocked further activation by IFN- $\alpha$ treatment (48). The unresponsiveness observed in the context of the unfavorable IFN- $\lambda 3 / 4$ alleles was shown to be driven by upregulation of USP18 (39). In liver biopsies from individuals with chronic HCV, it was also shown that the favorable IFN- $\lambda 4 \mathrm{rs} 368234815$ TT genotype was associated with increased degranulation capacity $(\mathrm{CD} 107 \mathrm{a}+)$ from $\mathrm{T}$, NK, and NKT cells, which correlated with serum ALT and AST levels (49). This suggests increased innate immune activation in the livers of these individuals.

Hepatocytes are not the only source of type III IFNs in the liver. Hepatic stellate cells (HSC), normally in a quiescent state, become activated following liver damage induced by HCV infection and may modulate intrahepatic immune responses. HSCs activated with the TLR-3 ligand poly I:C exhibit an antiviral effect when co-cultured with HCV-infected hepatocytes (50). Supernatants of activated HSCs demonstrated an antiviral effect that could be blocked by antibodies specific to the IL-10R2. These in vitro results strongly suggest that HSCs can participate in the innate immune response in the liver $v i a$ the production of IFN- $\lambda$.
Finally, DCs can also act as a key source and regulator of type III IFNs in the liver and the peripheral blood.

\section{IFN- $\lambda$ INTERACTION WITH HEMATOPOIETIC CELLS}

The interaction of type III IFNs with hematopoietic cells is not fully understood. In contrast to type I IFNs whose receptors are ubiquitously expressed, type III IFNs have a limited number of target cells, because their receptor (IFN- $\lambda$ R1 and IL-10R2 heterodimer) expression is highly restricted to the cells of epithelial origin including hepatocytes and few hematopoietic cells (4-7). Although, IFN- $\lambda$ R1 transcripts could be detected in several hematopoietic cells, it has been problematic to detect its expression on cell surface. It has also been reported that hematopoietic cells may express a soluble splice variant that may influence their capacity to respond to type III IFNs $(9,51)$. In the following sections, we will discuss in details the effect of type III IFNs on different types of hematopoietic cells.

\section{Monocytes and Macrophages}

It was shown that IFN- $\lambda \mathrm{R} 1$ was expressed on monocyte-derived macrophages, but not monocytes (52). Monocyte-derived macrophages responded to IFN- $\lambda 1$ treatment by phosphorylation of STAT-1 and increased production of cytokines such as tumor necrosis factor (TNF), IL-10, and IL-12p40 following TLR stimulation. Similar effects were observed after treatment with IFN- $\lambda 2$ or IFN- $\lambda 3$. Furthermore, contrary to IFN- $\alpha$, IFN- $\lambda 1$ enhanced cell surface expression of IFNGR1 on monocyte-derived macrophages, thus enhancing IL-12p40 and TNF production after stimulation with IFN- $\gamma$ (52). Polymorphism in the IFN- $\lambda 3$ SNP rs12979860 also impacted the activation of monocytes where individuals of the TT unfavorable genotype produced lower levels of IL-12 upon activation of their monocytes with the TLR ligand $\mathrm{R} 848$ (53). Thus, a better IFN- $\lambda$ response could potentiate the antiviral and inflammatory response of monocytes and may indirectly mediate viral clearance by boosting the induction and priming of the adaptive immune response.

\section{NK Cells}

Cytotoxic and antiviral functions of NK cells depend on a tightly regulated balance between activation and inhibitory signals. The main inhibitory mechanism is via binding of the killer cell-Ig-like receptors (KIR) with MHC class I molecules (54). The polymorphism within the KIR and MHC class I genes results in interactions of different strengths and degrees of activation of NK cells that correlate with $\mathrm{HCV}$ infectious outcome (55). IL-28B/IFN- $\lambda 3$, HLA-C, and KIR variants could additively predict response to IFN therapy in chronic HCV, suggesting a collaborative effort between type III IFNs and NK cells during viral clearance (56). Activation of NK cells, associated with the success of IFN-based treatment, was studied in relation to IFN- $\lambda 3$ polymorphism, and patients carrying the unfavorable IFN- $\lambda 3$ allele expressed higher levels of expression of the inhibitory receptor NKG2A on NK cells and were more likely not to respond to treatment (57). 
These observations further underscored the potential effect of type III IFNs on NK cells.

In the context of acute infection, KIR2DS 3 and the IFN- $\lambda 3$ SNP rs12979860 unfavorable T allele synergized to increase the risk of chronic infection (58). This study also suggested a direct link between IFN- $\lambda$ and NK cells, showing reduced IFN- $\gamma$ production by NK cells upon IFN- $\lambda$ treatment (58). However, these data were difficult to reproduce in other cohorts. The IFN- $\lambda 3$ rs12979860 CC genotype was associated with decreased levels of the inhibitory receptor NKG2A after infection resolution (31). Individuals bearing the $\mathrm{CC}$ genotype also displayed increased NK cell function measured by IFN- $\gamma$ production after stimulation irrespective of infectious outcome suggesting that IFN- $\lambda$ genotype influenced NK cell function but that this was not sufficient to achieve spontaneous HCV clearance (31). Although IFNLR1 mRNA expression could be detected in NK cells $(59,60)$, they express very low levels of the specific type III IFN receptor (IFN- $\lambda$ R1) on cell surface, even after IFN- $\alpha$ stimulation $(31,61$, 62). Treatment of purified NK cells with IFN- $\lambda$ had no effect on neither NK cytotoxicity nor cytokine production $(31,60,62,63)$. On the other hand, it was reported that the level of expression of IFN- $\lambda$ R 1 could be upregulated by IFN $-\lambda$ treatment (59) and studies in IFN- $\lambda \mathrm{R} 1^{-/-}$mice have demonstrated that this receptor is required for optimal antitumoral in vivo activity of $\mathrm{NK}$ cells (64), suggesting that in some activation context, NK cells could become sensitive to type III IFNs.

Given the lack of activation of NK cells by $\operatorname{IFN}-\lambda(31,60$, 62,63 ), indirect mechanism were investigated. IFN- $\lambda 1$ affected NK cells indirectly via the activation of monocyte derived macrophages. Macrophages activated by IFN- $\lambda 1$ produced cytokines of the IL-12 family (IL-12p40) that could then activate NK cells leading to increased IFN- $\gamma$ production. This activation was determined by polymorphisms in the IFN- $\lambda 3$ gene, and the presence of monocytes was essential (53). This suggests that $\mathrm{HCV}$-infected individuals bearing the unfavorable IFN- $\lambda 3$ allele have an impaired monocyte function. Monocytes can activate NK cells through the production of IL-12 or IL-18. Stimulated monocytes from CC genotype background produced significantly more IL-12p40 and IL-12p70 compared to monocytes of the CT or TT genotype. Blocking IL-12 and not IL-18 abolished the IFN- $\lambda$ association with the level of NK cell activation by monocytes, suggesting that IL-12 is a major player in the interplay between monocyte and NK cells that is associated with IFN- $\lambda 3$ genotype in $\mathrm{HCV}$-infected subjects (53).

Analysis of NK cell phenotype and function in chronic HCV infection demonstrated that CD56 $6^{\text {bright }} \mathrm{NK}$ cell subsets are significantly more cytotoxic than in healthy donors based on TRAIL and CD107a expression (65). This effect was independent of the IFN- $\lambda 3$ rs 12979860 genotype, but subjects carrying the TT genotype exhibited the highest levels of TRAIL+ and CD107a+IFN$\gamma+\mathrm{NK}$ cells. In the same study, CD $56^{\text {dim }} \mathrm{NK}$ cells of TT genotype individuals produced more TNF- $\alpha$. Accordingly, individuals with the TT genotype also had a higher proportion of polyfunctional NK cells (65).

In conclusion, whether by a direct or indirect mechanism, it appears that type III IFNs can modulate NK cells activation and functions but further investigation is required to identify the exact mechanism.

\section{Dendritic Cells}

Dendritic cells are important antigen-presenting cells and have a central role in mediating the link between the innate and adaptive immune response. DCs also are a major source of type III IFNs $(8,60,66)$. Stimulation of DCs (in vitro and ex vivo) with HCV RNA induced the production of both type I and type III IFNs and the levels were associated with IFN- $\lambda 3$ rs12979860 genotype, with the favorable CC allele leading to the highest IFN type III production (66). Type I and type III IFNs produced by DCs could control HCV replication in vitro, suggesting again an important role for type III IFN in HCV infection (66). During chronic HCV infection, serum levels of IFN- $\lambda 1$ were lower compared to $\mathrm{HCV}$ resolvers and healthy controls (29). In acute HCV infection, IFN- $\lambda 1$ serum levels were variable as described earlier $(29,31)$. Interestingly, HCV proteins $\mathrm{E} 2$ and NS3 inhibited IFN- $\lambda 1$ production by stimulated DCs, suggesting that IFN- $\lambda 1$ is an important immune mediator in HCV infection (29). On the other hand, treatment of DCs with IFN- $\lambda$ altered their function toward a dysfunctional help to T cells (7). IFN- $\lambda$-treated DCs exhibited decreased T cell stimulation capacity by upregulating PDL1 expression. In addition, IFN- $\lambda$-treated DCs promoted the expansion of regulatory $\mathrm{T}$ cells (Tregs), further impeding with the immune response. Further research will be needed to clarify the role of IFN- $\lambda$ and DCs during a viral infection, such as HCV.

\section{CD4 and CD8 T Cells}

The link between IFN- $\lambda$ and T cells is less studied compared to the link with cells of the innate immune response. A study by Bes et al. showed that CD4 T cell responses to HCV, assessed by IFN$\gamma$ enzyme-linked immunospot (ELISpot) assay, were of a higher frequency in the unfavorable allele (non CC) group (67). This was unexpected since a stronger immune response is normally associated with $\mathrm{HCV}$ spontaneous clearance. However, they tested a limited number of patient $(n=69$; with 38 samples with positive ELISpot response), and there was a lot of variability between samples. In a more recent study, Scheurich et al. tested the breadth and frequency of CD4 responses to HCV and stratified their results according to the IFN- $\lambda 3$ rs 12979860 genotype (68). However, they did not find any difference between the various IFN- $\lambda$ groups. Genetics studies showed that polymorphisms of MHC class I and MHC class II are associated with spontaneous clearance of HCV infection, independently of the IFN- $\lambda 3$ polymorphism $(69,70)$. Protective alleles were shown to have additive effect, suggesting that innate and adaptive immunity contribute independently to the prediction of a favorable outcome following acute $\mathrm{HCV}$ infection. However, these independent associations do not rule out the possibility that type III IFN could modulate CD4 T cells responses. Indeed, data from other models suggest that IFN- $\lambda$ can indeed impact CD4 T cells (71-73). It was reported that naive and memory CD4 T cells express IFN- $\lambda$ R 1 mRNA and that T cell stimulation in presence of IFN- $\lambda$ inhibited IL- 4 , IL- 5 , and IL-13 production, thus impeding the development of Th2 helper response without affecting cell proliferation $(72,73)$. IFN- $\lambda$ also 
inhibited the upregulation of IL-4R $\alpha$ on the surface of stimulated naive CD4 T cells, thus limiting the Th2 polarizing effect of IL-4 on these cells. IFN- $\lambda$-treated cells expressed significantly less GATA3, the transcription factor that is master regulator of Th2 differentiation, further supporting the hypothesis that IFN- $\lambda$ has inhibitory effect on the development of a Th2 response (73). Whether such mechanisms are implicated during HCV infection remains to be seen. It is also tempting to speculate that the effect of IFN- $\lambda$ polymorphism on production of IL-12 by monocytes may indirectly influence priming of the HCV-specific CD4 and CD8 $\mathrm{T}$ cells and the generation of antiviral Th1 responses.

\section{B Cells}

The role of the B cells and neutralizing antibody responses during acute HCV infection remains unclear. Some studies showed that early anti-HCV antibody response is associated with higher rate of spontaneous clearance of the virus during primary infection and reinfection (74-78), but other studies showed no association (79-82). To our knowledge, no data are currently available on the role of IFN- $\lambda$ polymorphisms in the B cell response against $\mathrm{HCV}$ but it can be inferred from other models. Generally, the role of IFN- $\lambda$ on B cells was only modestly studied. One recent article by de Groen et al. demonstrated that both naive and memory B cells express IFNLR1 mRNA and that IFN- $\lambda 1$ can activate B cells (83). Treatment of B cells with IFN- $\lambda 1$ led to increased expression of ISGs (Mx1 and OAS1) as well as increased expression of TLR7. IFN- $\lambda 1$ also enhanced IgM and IgG production from TLR7/8stimulated B cells. Finally, IFN- $\lambda 1$ stimulation increased the proliferation of B cells stimulated with TLR7/8 agonist. However, after TLR 2 or TLR9 stimulation, IFN- $\lambda 1$ had no effect on the antibody production or proliferation (83). Globally, this study suggests that IFN- $\lambda 1$ can enhance B cell response, but only under certain stimulation conditions.

In another context, Egli et al. showed that the IFN- $\lambda 3$ rs 8099917 GG genotype was associated with a higher rate of seroconversion after influenza vaccination in a cohort of immune-suppressed transplant patients (84). In addition, GG genotype carriers showed lower Th1 responses after PBMC stimulation with influenza antigens, suggesting that the IFN- $\lambda 3$ rs8099917 genotype can affect the Th1/Th2 balance. Accordingly, adding IFN- $\lambda 3$ in the stimulation medium increased the Th1 cytokine production and reduced Th2 cytokine production (84). These observations were confirmed in a cohort of healthy volunteers where IFN- $\lambda 3$ treatment enhanced Th1 cytokine profile and reduced production of Th2 cytokines after influenza stimulation (84). Also, IFN- $\lambda 3$ decreased $B$ cell proliferation and antibody production. Interestingly, it was also demonstrated that adding peptides that block the effect of IFN- $\lambda 3$ during the stimulation led to an increased antibody production, suggesting that blocking IFN- $\lambda 3$ during influenza vaccination could improve the seroconversion rate and thus have a better protective effect (84).

These two aforementioned studies used different type III IFNs to stimulate B cells (IFN- $\lambda 1$ or IFN- $\lambda 3$ ) as well as different antigenic stimulation. Hence, there is no clear conclusion on whether type III IFNs exert a beneficial or detrimental effect on $\mathrm{B}$ cell function and antibody production, and additional studies with standardized stimuli are warranted.

\section{SUMMARY OF THE ROLE OF TYPE III IFNS ON HEMATOPOIETIC CELLS}

Within the hematopoietic compartment, DCs are the main producers of IFN- $\lambda$, and they can travel between the liver and peripheral blood. The production of IFN- $\lambda$ by DCs can inhibit HCV RNA replication in hepatocytes. However, HCV proteins E2 and NS3 can also inhibit IFN- $\lambda$ production by DCs. Hematopoietic cells express variable levels and splice variants of IFN- $\lambda \mathrm{R} 1$, and conflicting results were obtained about the effect of IFN- $\lambda$ treatment on these cells. HCV exposed DCs or DCs treated with IFN- $\lambda$ display reduced stimulation of $\mathrm{T}$ cells by upregulating expression of PDL1 and enhanced proliferation of Tregs. Monocytes are responsive to IFN- $\lambda$ treatment resulting in IL-12 and IL-18 production. In turn, these cytokines can influence NK cell functions, and thus, IFN- $\lambda$ is an important component of the innate immune response to HCV. The role of IFN $-\lambda$ on CD4 and CD8 T cells as well as on B cells in the context of HCV remains understudied, but studies suggest that IFN- $\lambda$ could modulate the CD4 Th1/Th2 balance and can also have a positive or negative impact on IgG production by B cells (Figure 2).

\section{TYPE III IFNs AND HCV-SPECIFIC IMMUNITY DURING PREGNANCY}

In HCV-infected women, a sharp decrease in HCV viral load is sometimes observed after childbirth, suggestive of a boost in the immune response following delivery $(85,86)$. It was recently demonstrated that beside a stronger $\mathrm{T}$ cell response, the presence of the favorable CC IFN- $\lambda 3$ rs12979860 genotype was significantly associated with this high decrease in viral load (87). Considering the high linkage disequilibrium between IFN$\lambda 3$ rs12979860 genotype and IFN- $\lambda 4$ rs368234815 genotype, the IFN- $\lambda 4$ was also associated with the decrease in viral load postpartum (87). It is well known that women's immune system is altered through pregnancy to avoid a reaction against the fetus (88). It is postulated that the innate immune system will play a significant role against pathogens, while the adaptive immune responses are dampened by increased Tregs activity $(89,90)$. Another recent study showed that the expression of innate immunity genes is enriched in postpartum women compared to control (91). Interestingly, ISGs level in women of the CT or TT IFN $-\lambda 3$ rs12979860 genotype remained elevated as late as 24 weeks after childbirth, while women with the CC IFN- $\lambda 3$ genotype were comparable to non-pregnant controls (91). This reflects what was observed in the context of acute HCV where individuals with non-favorable CT or TT IFN- $\lambda 3$ genotype had a higher baseline ISG expression in the liver.

\section{IFN- $\lambda$ DURING TREATMENT WITH DIRECT-ACTING ANTIVIRALS (DAA) AND HCV-RELATED LIVER DISEASE}

With the development of novel DAAs that are highly effective $(\sim 100 \%)$ against most genotypes, treatment has switched to IFNfree regimens. Limited studies have indicated that polymorphism 


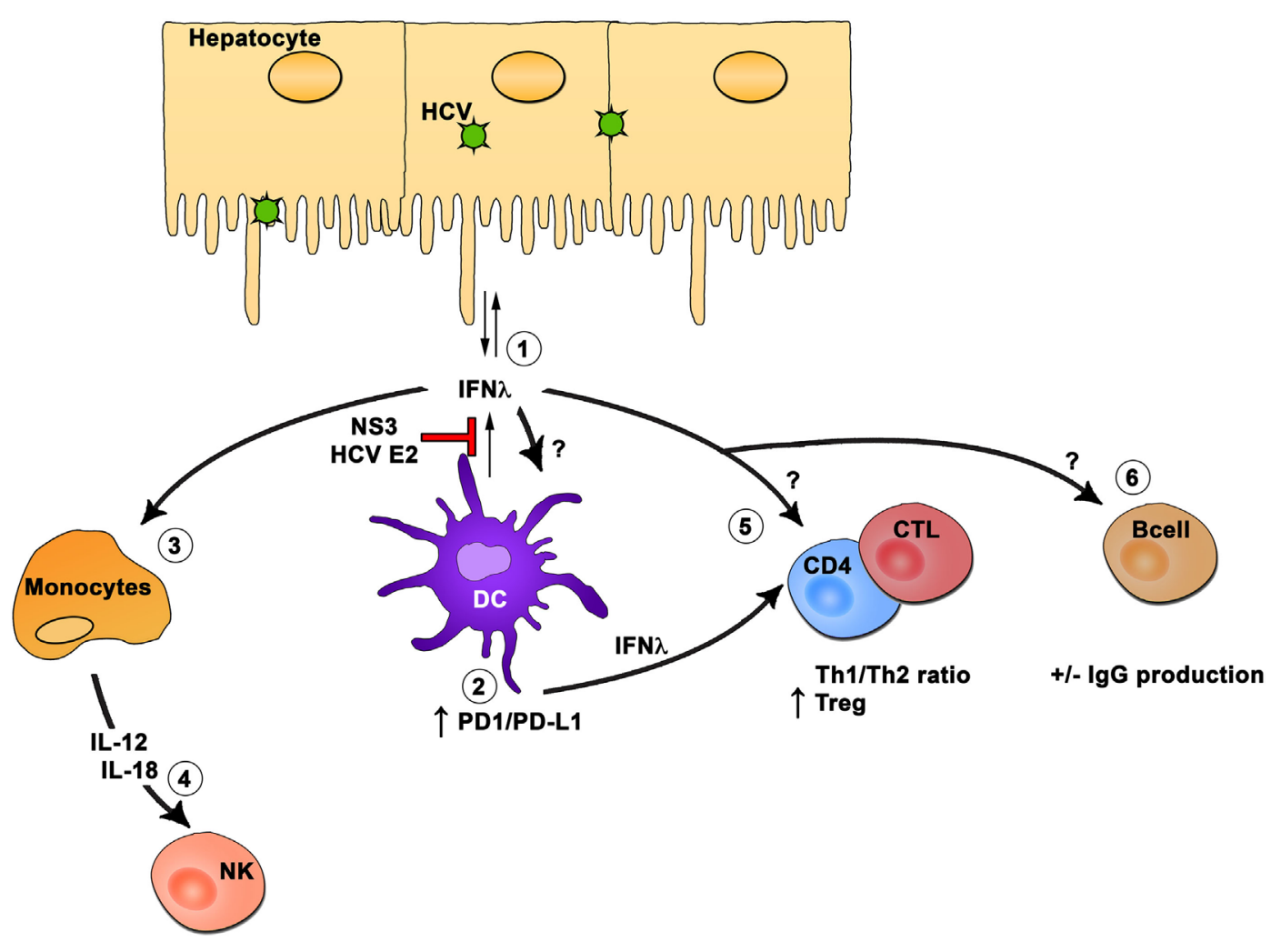

FIGURE 2 | Interferon (IFN)- $\lambda$ modulation of hematopoietic cells. In the hematopoietic compartment, dendritic cells (DCs) are the main producers of IFN- $\lambda$ (1). The production of IFN- $\lambda$ by DCs can inhibit hepatitis C virus (HCV) RNA replication in hepatocytes. However, HCV proteins E2 and NS3 can inhibit IFN- $\lambda$ production by DCs. Hematopoietic cells express variable levels and splice variants of IFN- $\lambda$ R1, and conflicting results were obtained about the effect of IFN- $\lambda$ treatment on these cells. HCV-exposed DCs or DC treated with IFN- $\lambda$ display reduced stimulation of T cells through upregulation of PDL1 and enhanced proliferation of regulatory T cells (2). Monocytes are responsive to IFN- $\lambda$ treatment resulting in interleukin (IL)-12 and IL-18 production (3). In turn, these cytokines will influence natural killer cell function (4), and thus, IFN- $\lambda$ is an important component of the innate immune response to HCV. The role of IFN- $\lambda$ on CD4 and CD8 T cells (5) as well as on B cells (6) in the context of HCV remains understudied, but studies suggest that IFN- $\lambda$ could modulate the CD4 Th1/Th2 ratio and can also have a positive or negative impact on IgG production by B cells.

in the IFN- $\lambda$ region may influence the response to DAAs, especially if IFN is still used in the combination $(92,93)$. However, given the high rate of response to DAAs and the availability of multiple products on the market, IFN- $\lambda$ has lost its predictive value, and testing for it before treatment is no longer recommended except in specific situations where a DAA and IFN combination may still be warranted (94).

Chronic HCV infection is associated with an increased risk of liver-related illness, such as fibrosis, cirrhosis, and hepatocellular carcinoma (HCC). The link between IFN- $\lambda$ polymorphisms and HCV-related liver disease is not completely clear and was reviewed in detail elsewhere (95). One study showed that the favorable CC IFN- $\lambda 3$ rs12979860 allele, associated with better chance of HCV clearance, is also associated with higher blood ALT levels, indicative of increased liver inflammation. However, IFN- $\lambda$ rs12979860 polymorphism was not associated with fibrosis progression in the same cohort (96). Another study did not find any association of the IFN- $\lambda$ polymorphism with any of the observed associated liver illness (decompensated cirrhosis, HCC, liver-related death, and all-cause mortality) (97). On the other hand, Bochud et al. demonstrated that particularly in non-genotype $1 \mathrm{HCV}$-infected individuals, the favorable IFN- $\lambda$ alleles were associated with increased inflammation and higher fibrosis scores (98). In agreement with this, Eslam et al. observed a significant association between IFN- $\lambda 3$ rs 12979860 polymorphism and liver necroinflammatory activity, serum level of AST and ALT, as well as fibrosis score and progression (99). Once again the association was stronger in individuals infected with HCV genotype 3 than those infected with HCV genotype 1. Also, in patients carrying the IFN- $\lambda 4$ rs368234815 unfavorable allele $(\Delta \mathrm{G})$, there was a correlation between the frequency of CD107a expressing cells and the serum ALT levels, suggestive of increased liver damage (49). In the context of HCC, two studies associated IFN- $\lambda 3$ rs12979860 unfavorable CT or TT alleles with liver cirrhosis and the development of HCC in patients chronically infected with HCV $(100,101)$. However, this was not confirmed in two other independent studies in Japanese (102) or Italian cohorts (97). Finally, HCV-related liver disease is a multifactorial problem, and the independent association of genetic factors may not be a clear cut. Fortunately, with the development of highly effective DAAs, it is expected that these complications will be less frequent as SVR will be achievable in most patients. 


\section{CONCLUDING REMARKS}

Type III IFNs exhibit strong antiviral activity, and yet, the expression of a functional IFN $\lambda$ 4 protein was strongly associated with failure to clear HCV infection either spontaneously or after IFN-based treatment. A recent study suggested that humans suppress IFN- $\lambda 4$ expression through various mechanisms and hence immune functions may be dependent on other type III IFNs (103). Data accumulated so far suggest that a higher baseline ISG expression level is associated with induction of a refractory state, where further IFN treatment has no beneficial effect. With the new era of anti-HCV IFN-free DAA therapies, the role of type III IFNs during therapy has become somewhat irrelevant but its role in mediating spontaneous clearance during acute $\mathrm{HCV}$ infection and modulating the cross-talk between innate and adaptive immunity remains highly pertinent. This is applicable not only for $\mathrm{HCV}$ infection but also for other viral infections and response to vaccines. Furthermore, the recently described role of type III IFN polymorphisms in driving immunity postpartum is

\section{REFERENCES}

1. Kotenko SV, Gallagher G, Baurin VV, Lewis-Antes A, Shen M, Shah NK, et al. IFN-lambdas mediate antiviral protection through a distinct class II cytokine receptor complex. Nat Immunol (2003) 4:69-77. doi:10.1038/ni875

2. Sheppard P, Kindsvogel W, Xu W, Henderson K, Schlutsmeyer S, Whitmore TE, et al. IL-28, IL-29 and their class II cytokine receptor IL-28R. Nat Immunol (2003) 4:63-8. doi:10.1038/ni873

3. Prokunina-Olsson L, Muchmore B, Tang W, Pfeiffer RM, Park H, Dickensheets $\mathrm{H}$, et al. A variant upstream of IFNL3 (IL28B) creating a new interferon gene IFNL4 is associated with impaired clearance of hepatitis C virus. Nat Genet (2013) 45:164-71. doi:10.1038/ng.2521

4. de Weerd NA, Nguyen T. The interferons and their receptors - distribution and regulation. Immunol Cell Biol (2012) 90:483-91. doi:10.1038/icb.2012.9

5. Doyle SE, Schreckhise H, Khuu-Duong K, Henderson K, Rosler R, Storey $\mathrm{H}$, et al. Interleukin-29 uses a type 1 interferon-like program to promote antiviral responses in human hepatocytes. Hepatology (2006) 44:896-906. doi:10.1002/hep. 21312

6. Sommereyns C, Paul S, Staeheli P, Michiels T. IFN-lambda (IFN-lambda) is expressed in a tissue-dependent fashion and primarily acts on epithelial cells in vivo. PLoS Pathog (2008) 4:e1000017. doi:10.1371/journal.ppat.1000017

7. Dolganiuc A, Kodys K, Marshall C, Saha B, Zhang S, Bala S, et al. Type III interferons, IL-28 and IL-29, are increased in chronic HCV infection and induce myeloid dendritic cell-mediated FoxP3+ regulatory T cells. PLoS One (2012) 7:e44915. doi:10.1371/journal.pone.0044915

8. Yin Z, Dai J, Deng J, Sheikh F, Natalia M, Shih T, et al. Type III IFNs are produced by and stimulate human plasmacytoid dendritic cells. J Immunol (2012) 189:2735-45. doi:10.4049/jimmunol.1102038

9. Witte K, Gruetz G, Volk HD, Looman AC, Asadullah K, Sterry W, et al. Despite IFN-lambda receptor expression, blood immune cells, but not keratinocytes or melanocytes, have an impaired response to type III interferons: implications for therapeutic applications of these cytokines. Genes Immun (2009) 10:702-14. doi:10.1038/gene.2009.72

10. Hoofnagle JH. Course and outcome of hepatitis C. Hepatology (2002) 36:S21-9. doi:10.1053/jhep.2002.36227

11. Elbaz T, El-Kassas M, Esmat G. New era for management of chronic hepatitis C virus using direct antiviral agents: a review. J Adv Res (2015) 6:301-10. doi:10.1016/j.jare.2014.11.004

12. Hadziyannis SJ, Sette H Jr, Morgan TR, Balan V, Diago M, Marcellin P, et al. Peginterferon-alpha2a and ribavirin combination therapy in chronic hepatitis C: a randomized study of treatment duration and ribavirin dose. Ann Intern Med (2004) 140:346-55. doi:10.7326/0003-4819-140-5-200403020-00010 just the tip of the iceberg as it will become increasingly relevant to mother-infant health and vertical transmission of various pathogens.

\section{AUTHOR CONTRIBUTIONS}

Both the authors reviewed the literature and wrote this manuscript.

\section{ACKNOWLEDGMENTS}

The authors would like to thank Thomas Fabre for preparation of the figures. Their research is funded by the Canadian Institutes of Health Research (CIHR) (MOP-133680), Alberta Innovates Health Solutions and the Canadian Liver Foundation. MB is supported by postdoctoral fellowships from the American Liver Foundation, the Fonds de Recherche du Québec-Santé (FRQS), and the Canadian Network on Hepatitis C (CanHepC). NS is supported by a Chercheur Boursier salary award from the FRQS.

13. Swain MG, Lai MY, Shiffman ML, Cooksley WG, Zeuzem S, Dieterich DT, et al. A sustained virologic response is durable in patients with chronic hepatitis $\mathrm{C}$ treated with peginterferon alfa- $2 \mathrm{a}$ and ribavirin. Gastroenterology (2010) 139:1593-601. doi:10.1053/j.gastro.2010.07.009

14. Chen SL, Morgan TR. The natural history of hepatitis C virus (HCV) infection. Int J Med Sci (2006) 3:47-52. doi:10.7150/ijms.3.47

15. Rauch A, Gaudieri S, Thio C, Bochud PY. Host genetic determinants of spontaneous hepatitis C clearance. Pharmacogenomics (2009) 10:1819-37. doi:10.2217/pgs.09.121

16. Manka C, Gomes R, Reviere R, Lee C. Treatment options for hepatitis C and the rationale for low response rates in African Americans. J Natl Med Assoc (2009) 101:604-8. doi:10.1016/S0027-9684(15)30948-2

17. Ge D, Fellay J, Thompson AJ, Simon JS, Shianna KV, Urban TJ, et al. Genetic variation in IL28B predicts hepatitis C treatment-induced viral clearance. Nature (2009) 461:399-401. doi:10.1038/nature08309

18. Suppiah V, Moldovan M, Ahlenstiel G, Berg T, Weltman M, Abate ML, et al. IL28B is associated with response to chronic hepatitis $\mathrm{C}$ interferon-alpha and ribavirin therapy. Nat Genet (2009) 41:1100-4. doi:10.1038/ng.447

19. Tanaka Y, Nishida N, Sugiyama M, Kurosaki M, Matsuura K, Sakamoto N, et al. Genome-wide association of IL28B with response to pegylated interferon-alpha and ribavirin therapy for chronic hepatitis C. Nat Genet (2009) 41:1105-9. doi:10.1038/ng.449

20. Thomas DL, Thio CL, Martin MP, Qi Y, Ge D, O'huigin C, et al. Genetic variation in IL28B and spontaneous clearance of hepatitis C virus. Nature (2009) 461:798-801. doi:10.1038/nature08463

21. Rauch A, Kutalik Z, Descombes P, Cai T, Di Iulio J, Mueller T, et al. Genetic variation in IL28B is associated with chronic hepatitis $\mathrm{C}$ and treatment failure: a genome-wide association study. Gastroenterology (2010) 138:1338-5, 1345.e1331-7. doi:10.1053/j.gastro.2009.12.056

22. Tillmann HL, Thompson AJ, Patel K, Wiese M, Tenckhoff H, Nischalke HD, et al. A polymorphism near IL28B is associated with spontaneous clearance of acute hepatitis C virus and jaundice. Gastroenterology (2010) 139(1586-1592):1592e1581. doi:10.1053/j.gastro.2010.07.005

23. Sacks-Davis R, Grebely J, Dore GJ, Osburn W, Cox AL, Rice TM, et al. Hepatitis $C$ virus reinfection and spontaneous clearance of reinfection - the InC3 study. J Infect Dis (2015) 212:1407-19. doi:10.1093/infdis/jiv220

24. O'Brien TR, Prokunina-Olsson L, Donnelly RP. IFN-lambda4: the paradoxical new member of the interferon lambda family. J Interferon Cytokine Res (2014) 34:829-38. doi:10.1089/jir.2013.0136

25. Aka PV, Kuniholm MH, Pfeiffer RM, Wang AS, Tang W, Chen S, et al. Association of the IFNL4-DeltaG allele with impaired spontaneous clearance of hepatitis C virus. J Infect Dis (2014) 209:350-4. doi:10.1093/infdis/jit433 
26. O'Brien TR, Pfeiffer RM, Paquin A, Lang Kuhs KA, Chen S, Bonkovsky HL, et al. Comparison of functional variants in IFNL4 and IFNL3 for association with HCV clearance. J Hepatol (2015) 63:1103-10. doi:10.1016/j. jhep.2015.06.035

27. Bibert S, Roger T, Calandra T, Bochud M, Cerny A, Semmo N, et al. IL28B expression depends on a novel TT/-G polymorphism which improves HCV clearance prediction. JExp Med (2013) 210:1109-16. doi:10.1084/ jem.20130012

28. Park H, Serti E, Eke O, Muchmore B, Prokunina-Olsson L, Capone S, et al. IL-29 is the dominant type III interferon produced by hepatocytes during acute hepatitis C virus infection. Hepatology (2012) 56:2060-70. doi:10.1002/ hep. 25897

29. Langhans B, Kupfer B, Braunschweiger I, Arndt S, Schulte W, Nischalke $\mathrm{HD}$, et al. Interferon-lambda serum levels in hepatitis C. J Hepatol (2011) 54:859-65. doi:10.1016/j.jhep.2010.08.020

30. Torres C, Brahm J, Venegas M. Lambda interferon serum levels in patients with chronic hepatitis $\mathrm{C}$ virus infection according to their response to therapy with pegylated interferon and ribavirin. J Interferon Cytokine Res (2014) 34:106-10. doi:10.1089/jir.2013.0005

31. Depla M, Pelletier S, Bedard N, Brunaud C, Bruneau J, Shoukry NH. IFN-lambda3 polymorphism indirectly influences NK cell phenotype and function during acute HCV infection. Immun Inflamm Dis (2016) 4:376-88. doi:10.1002/iid3.122

32. Hamming OJ, Terczynska-Dyla E, Vieyres G, Dijkman R, Jorgensen SE, Akhtar $\mathrm{H}$, et al. Interferon lambda 4 signals via the IFNlambda receptor to regulate antiviral activity against HCV and coronaviruses. EMBO J (2013) 32:3055-65. doi:10.1038/emboj.2013.232

33. Bordi L, Caglioti C, Garbuglia AR, Lapa D, Castilletti C, Taibi C, et al. IFNL4 and IFNL3 associated polymorphisms strongly influence the spontaneous IFN-alpha receptor-1 expression in HCV-infected patients. PLoS One (2015) 10:e0117397. doi:10.1371/journal.pone.0117397

34. Chen L, Borozan I, Feld J, Sun J, Tannis LL, Coltescu C, et al. Hepatic gene expression discriminates responders and nonresponders in treatment of chronic hepatitis C viral infection. Gastroenterology (2005) 128:1437-44. doi:10.1053/j.gastro.2005.01.059

35. Feld JJ, Nanda S, Huang Y, Chen W, Cam M, Pusek SN, et al. Hepatic gene expression during treatment with peginterferon and ribavirin: identifying molecular pathways for treatment response. Hepatology (2007) 46:1548-63. doi:10.1002/hep. 21853

36. Asselah T, Bieche I, Narguet S, Sabbagh A, Laurendeau I, Ripault MP, et al. Liver gene expression signature to predict response to pegylated interferon plus ribavirin combination therapy in patients with chronic hepatitis C. Gut (2008) 57:516-24. doi:10.1136/gut.2007.128611

37. Honda M, Sakai A, Yamashita T, Nakamoto Y, Mizukoshi E, Sakai Y, et al. Hepatic ISG expression is associated with genetic variation in interleukin $28 \mathrm{~B}$ and the outcome of IFN therapy for chronic hepatitis C. Gastroenterology (2010) 139:499-509. doi:10.1053/j.gastro.2010.04.049

38. Urban TJ, Thompson AJ, Bradrick SS, Fellay J, Schuppan D, Cronin KD, et al. IL28B genotype is associated with differential expression of intrahepatic interferon-stimulated genes in patients with chronic hepatitis C. Hepatology (2010) 52:1888-96. doi:10.1002/hep.23912

39. Sung PS, Cheon H, Cho CH, Hong SH, Park DY, Seo HI, et al. Roles of unphosphorylated ISGF3 in HCV infection and interferon responsiveness. Proc Natl Acad Sci U S A (2015) 112:10443-8. doi:10.1073/pnas. 1513341112

40. Sarasin-Filipowicz M, Oakeley EJ, Duong FH, Christen V, Terracciano L, Filipowicz W, et al. Interferon signaling and treatment outcome in chronic hepatitis C. Proc Natl Acad Sci U S A (2008) 105:7034-9. doi:10.1073/ pnas. 0707882105

41. Terczynska-Dyla E, Bibert S, Duong FH, Krol I, Jorgensen S, Collinet E, et al. Reduced IFNlambda4 activity is associated with improved HCV clearance and reduced expression of interferon-stimulated genes. Nat Commun (2014) 5:5699. doi:10.1038/ncomms6699

42. Bigger CB, Brasky KM, Lanford RE. DNA microarray analysis of chimpanzee liver during acute resolving hepatitis C virus infection. J Virol (2001) 75:7059-66. doi:10.1128/JVI.75.15.7059-7066.2001

43. Su AI, Pezacki JP, Wodicka L, Brideau AD, Supekova L, Thimme R, et al. Genomic analysis of the host response to hepatitis $\mathrm{C}$ virus infection. Proc Natl Acad Sci U S A (2002) 99:15669-74. doi:10.1073/pnas.202608199
44. Thomas E, Gonzalez VD, Li Q, Modi AA, Chen W, Noureddin M, et al. $\mathrm{HCV}$ infection induces a unique hepatic innate immune response associated with robust production of type III interferons. Gastroenterology (2012) 142:978-88. doi:10.1053/j.gastro.2011.12.055

45. Marukian S, Andrus L, Sheahan TP, Jones CT, Charles ED, Ploss A, et al. Hepatitis $\mathrm{C}$ virus induces interferon-lambda and interferon-stimulated genes in primary liver cultures. Hepatology (2011) 54(6):1913-23. doi:10.1002/ hep. 24580

46. Sheahan T, Imanaka N, Marukian S, Dorner M, Liu P, Ploss A, et al. Interferon lambda alleles predict innate antiviral immune responses and hepatitis $\mathrm{C}$ virus permissiveness. Cell Host Microbe (2014) 15:190-202. doi:10.1016/ j.chom.2014.01.007

47. Onabajo OO, Porter-Gill P, Paquin A, Rao N, Liu L, Tang W, et al. Expression of interferon lambda 4 is associated with reduced proliferation and increased cell death in human hepatic cells. J Interferon Cytokine Res (2015) 35:888-900. doi:10.1089/jir.2014.0161

48. Ferraris P, Chandra PK, Panigrahi R, Aboulnasr F, Chava S, Kurt R, et al. Cellular mechanism for impaired hepatitis $\mathrm{C}$ virus clearance by interferon associated with IFNL3 gene polymorphisms relates to intrahepatic interferon-lambda expression. Am J Pathol (2016) 186:938-51. doi:10.1016/ j.ajpath.2015.11.027

49. Jouvin-Marche E, Macek Jilkova Z, Thelu MA, Marche H, Fugier E, Van Campenhout $\mathrm{N}$, et al. Lymphocytes degranulation in liver in hepatitis $\mathrm{C}$ virus carriers is associated with IFNL4 polymorphisms and ALT levels. J Infect Dis (2014) 209:1907-15. doi:10.1093/infdis/jiu016

50. Wang Y, Li J, Wang X, Ye L, Zhou Y, Ho W. Induction of interferon-lambda contributes to toll-like receptor-3-activated hepatic stellate cell-mediated hepatitis C virus inhibition in hepatocytes. J Viral Hepat (2013) 20:385-94. doi:10.1111/jvh.12040

51. Witte K, Witte E, Sabat R, Wolk K. IL-28A, IL-28B, and IL-29: promising cytokines with type I interferon-like properties. Cytokine Growth Factor Rev (2010) 21:237-51. doi:10.1016/j.cytogfr.2010.04.002

52. Liu BS, Janssen HL, Boonstra A. IL-29 and IFNalpha differ in their ability to modulate IL-12 production by TLR-activated human macrophages and exhibit differential regulation of the IFNgamma receptor expression. Blood (2011) 117:2385-95. doi:10.1182/blood-2010-07-298976

53. Kramer B, Finnemann C, Sastre B, Lutz P, Glassner A, Wolter F, et al. IL-28B genetic variants determine the extent of monocyte-induced activation of NK cells in hepatitis C. PLoS One (2016) 11:e0162068. doi:10.1371/journal. pone. 0162068

54. Shoukry NH, Pelletier S, Chang KM. A view to natural killer cells in hepatitis C. Gastroenterology (2011) 141:1144-8. doi:10.1053/j.gastro.2011.08.025

55. Khakoo SI, Thio CL, Martin MP, Brooks CR, Gao X, Astemborski J, et al. HLA and $\mathrm{NK}$ cell inhibitory receptor genes in resolving hepatitis $\mathrm{C}$ virus infection. Science (2004) 305:872-4. doi:10.1126/science.1097670

56. Suppiah V, Gaudieri S, Armstrong NJ, O'connor KS, Berg T, Weltman $\mathrm{M}$, et al. IL28B, HLA-C, and KIR variants additively predict response to therapy in chronic hepatitis C virus infection in a European Cohort: a cross-sectional study. PLoS Med (2011) 8:e1001092. doi:10.1371/journal. pmed.1001092

57. Golden-Mason L, Bambha KM, Cheng L, Howell CD, Taylor MW, Clark PJ, et al. Natural killer inhibitory receptor expression associated with treatment failure and interleukin-28B genotype in patients with chronic hepatitis C. Hepatology (2011) 54:1559-69. doi:10.1002/hep.24556

58. Dring MM, Morrison MH, Mcsharry BP, Guinan KJ, Hagan R, Irish HCVRC, et al. Innate immune genes synergize to predict increased risk of chronic disease in hepatitis C virus infection. Proc Natl Acad Sci U S A (2011) 108:5736-41. doi:10.1073/pnas.1016358108

59. Gardiner CM, Morrison MH, Dring MM. Reply to Krämer et al.: human natural killer (NK) cell inhibition by IL28A. Proc Natl Acad Sci U S A (2011) 108:E521-2. doi:10.1073/pnas.1109288108

60. O'Connor KS, Ahlenstiel G, Suppiah V, Schibeci S, Ong A, Leung R, et al. IFNL3 mediates interaction between innate immune cells: implications for hepatitis C virus pathogenesis. Innate Immun (2014) 20:598-605. doi:10.1177/1753425913503385

61. Kramer B, Eisenhardt M, Glassner A, Korner C, Sauerbruch T, Spengler U, et al. Do lambda-IFNs IL28A and IL28B act on human natural killer cells? Proc Natl Acad Sci U S A (2011) 108:E519-20. doi:10.1073/pnas. 1108850108 
62. de Groen RA, Boltjes A, Hou J, Liu BS, Mcphee F, Friborg J, et al. IFNlambda-mediated IL-12 production in macrophages induces IFN-gamma production in human NK cells. Eur J Immunol (2015) 45:250-9. doi:10.1002/ eji.201444903

63. Morrison MH, Keane C, Quinn LM, Kelly A, O'farrelly C, Bergin C, et al. IFNL cytokines do not modulate human or murine NK cell functions. Hum Immunol (2014) 75:996-1000. doi:10.1016/j.humimm.2014.06.016

64. Souza-Fonseca-Guimaraes F, Young A, Mittal D, Martinet L, Bruedigam C, Takeda K, et al. NK cells require IL-28R for optimal in vivo activity. Proc Natl Acad Sci U S A (2015) 112:E2376-84. doi:10.1073/pnas.1424241112

65. Rogalska-Taranta M, Markova AA, Taranta A, Lunemann S, Schlaphoff V, Flisiak R, et al. Altered effector functions of NK cells in chronic hepatitis C are associated with IFNL3 polymorphism. J Leukoc Biol (2015) 98:283-94. doi:10.1189/jlb.4A1014-520R

66. Stone AE, Giugliano S, Schnell G, Cheng L, Leahy KF, Golden-Mason L, et al. Hepatitis $C$ virus pathogen associated molecular pattern (PAMP) triggers production of lambda-interferons by human plasmacytoid dendritic cells. PLoS Pathog (2013) 9:e1003316. doi:10.1371/journal.ppat.1003316

67. Bes M, Sauleda S, Campos-Varela I, Rodriguez-Frias F, Casamitjana N, Homs M, et al. IL28B genetic variation and hepatitis C virus-specific CD4(+) T-cell responses in anti-HCV-positive blood donors. J Viral Hepat (2012) 19:867-71. doi:10.1111/j.1365-2893.2012.01631.x

68. Scheurich C, Schulze Zur Wiesch J, Kim AY, Lewis-Ximenez L, Meyer T, Polywka S, et al. Breadth of the HCV-specific CD4+ T-cell response in spontaneous resolvers is independent of the IL-28 haplotype. J Viral Hepat (2016) 23(10):831-2. doi:10.1111/jvh.12560

69. Duggal P, Thio CL, Wojcik GL, Goedert JJ, Mangia A, Latanich R, et al. Genome-wide association study of spontaneous resolution of hepatitis C virus infection: data from multiple cohorts. Ann Intern Med (2013) 158:235-45. doi:10.7326/0003-4819-158-4-201302190-00003

70. Fitzmaurice K, Hurst J, Dring M, Rauch A, Mclaren PJ, Gunthard HF, et al. Additive effects of HLA alleles and innate immune genes determine viral outcome in HCV infection. Gut (2015) 64:813-9. doi:10.1136/ gutjnl-2013-306287

71. Jordan WJ, Eskdale J, Srinivas S, Pekarek V, Kelner D, Rodia M, et al. Human interferon lambda-1 (IFN-lambda1/IL-29) modulates the Th1/Th2 response. Genes Immun (2007) 8:254-61. doi:10.1038/sj.gene.6364348

72. Srinivas S, Dai J, Eskdale J, Gallagher GE, Megjugorac NJ, Gallagher G. Interferon-lambdal (interleukin-29) preferentially down-regulates interleukin-13 over other T helper type 2 cytokine responses in vitro. Immunology (2008) 125:492-502. doi:10.1111/j.1365-2567.2008.02862.x

73. Dai J, Megjugorac NJ, Gallagher GE, Yu RY, Gallagher G. IFN-lambda1 (IL-29) inhibits GATA3 expression and suppresses Th2 responses in human naive and memory T cells. Blood (2009) 113:5829-38. doi:10.1182/ blood-2008-09-179507

74. Pestka JM, Zeisel MB, Blaser E, Schurmann P, Bartosch B, Cosset FL, et al. Rapid induction of virus-neutralizing antibodies and viral clearance in a single-source outbreak of hepatitis C. Proc Natl Acad Sci U S A (2007) 104:6025-30. doi:10.1073/pnas.0607026104

75. Osburn WO, Fisher BE, Dowd KA, Urban G, Liu L, Ray SC, et al. Spontaneous control of primary hepatitis $\mathrm{C}$ virus infection and immunity against persistent reinfection. Gastroenterology (2010) 138:315-24. doi:10.1053/ j.gastro.2009.09.017

76. Raghuraman S, Park H, Osburn WO, Winkelstein E, Edlin BR, Rehermann B. Spontaneous clearance of chronic hepatitis $\mathrm{C}$ virus infection is associated with appearance of neutralizing antibodies and reversal of T-cell exhaustion. J Infect Dis (2012) 205:763-71. doi:10.1093/infdis/jir835

77. Esteban-Riesco L, Depaulis F, Moreau A, Bacq Y, Dubois F, Goudeau A, et al. Rapid and sustained autologous neutralizing response leading to early spontaneous recovery after HCV infection. Virology (2013) 444:90-9. doi:10.1016/j.virol.2013.05.037

78. Osburn WO, Snider AE, Wells BL, Latanich R, Bailey JR, Thomas DL, et al. Clearance of hepatitis $\mathrm{C}$ infection is associated with the early appearance of broad neutralizing antibody responses. Hepatology (2014) 59:2140-51. doi:10.1002/hep. 27013

79. Thimme R, Bukh J, Spangenberg HC, Wieland S, Pemberton J, Steiger C, et al. Viral and immunological determinants of hepatitis $\mathrm{C}$ virus clearance, persistence, and disease. Proc Natl Acad Sci U S A (2002) 99:15661-8. doi:10.1073/pnas.202608299

80. Logvinoff C, Major ME, Oldach D, Heyward S, Talal A, Balfe P, et al. Neutralizing antibody response during acute and chronic hepatitis $\mathrm{C}$ virus infection. Proc Natl Acad Sci U S A (2004) 101:10149-54. doi:10.1073/ pnas.0403519101

81. Post JJ, Pan Y, Freeman AJ, Harvey CE, White PA, Palladinetti P, et al. Clearance of hepatitis $C$ viremia associated with cellular immunity in the absence of seroconversion in the hepatitis $\mathrm{C}$ incidence and transmission in prisons study cohort. J Infect Dis (2004) 189:1846-55. doi:10.1086/ 383279

82. Meyer MF, Lehmann M, Cornberg M, Wiegand J, Manns MP, Klade C, et al. Clearance of low levels of HCV viremia in the absence of a strong adaptive immune response. Virol J (2007) 4:58. doi:10.1186/1743-422X-4-58

83. de Groen RA, Groothuismink ZM, Liu BS, Boonstra A. IFN-lambda is able to augment TLR-mediated activation and subsequent function of primary human B cells. J Leukoc Biol (2015) 98:623-30. doi:10.1189/jlb.3A0215-041RR

84. Egli A, Santer DM, O'shea D, Barakat K, Syedbasha M, Vollmer M, et al. IL-28B is a key regulator of $\mathrm{B}$ - and T-cell vaccine responses against influenza. PLoS Pathog (2014) 10:e1004556. doi:10.1371/journal.ppat.1004556

85. Gervais A, Bacq Y, Bernuau J, Martinot M, Auperin A, Boyer N, et al. Decrease in serum ALT and increase in serum HCV RNA during pregnancy in women with chronic hepatitis C. J Hepatol (2000) 32:293-9. doi:10.1016/ S0168-8278(00)80075-6

86. Lin $\mathrm{HH}, \mathrm{Kao} \mathrm{JH}$. Hepatitis $\mathrm{C}$ virus load during pregnancy and puerperium. BJOG (2000) 107:1503-6. doi:10.1111/j.1471-0528.2000.tb11675.x

87. Honegger JR, Tedesco D, Kohout JA, Prasad MR, Price AA, Lindquist T, et al. Influence of IFNL3 and HLA-DPB1 genotype on postpartum control of hepatitis $\mathrm{C}$ virus replication and T-cell recovery. Proc Natl Acad Sci U S A (2016) 113:10684-9. doi:10.1073/pnas.1602337113

88. Erlebacher A. Mechanisms of T cell tolerance towards the allogeneic fetus. Nat Rev Immunol (2013) 13:23-33. doi:10.1038/nri3361

89. Sacks G, Sargent I, Redman C. An innate view of human pregnancy. Immunol Today (1999) 20:114-8. doi:10.1016/S0167-5699(98)01393-0

90. Aluvihare VR, Kallikourdis M, Betz AG. Regulatory T cells mediate maternal tolerance to the fetus. Nat Immunol (2004) 5:266-71. doi:10.1038/ ni1037

91. Price AA, Tedesco D, Prasad MR, Workowski KA, Walker CM, Suthar MS, et al. Prolonged activation of innate antiviral gene signature after childbirth is determined by IFNL3 genotype. Proc Natl Acad Sci U S A (2016) 113:10678-83. doi:10.1073/pnas.1602319113

92. Poordad F, Bronowicki JP, Gordon SC, Zeuzem S, Jacobson IM, Sulkowski MS, et al. Factors that predict response of patients with hepatitis $\mathrm{C}$ virus infection to boceprevir. Gastroenterology (2012) 143: 608-618.e601-5. doi:10.1053/j.gastro.2012.05.011

93. O’Brien TR, Lang Kuhs KA, Pfeiffer RM. Subgroup differences in response to 8 weeks of ledipasvir/sofosbuvir for chronic hepatitis C. Open Forum Infect Dis (2014) 1:ofu110. doi:10.1093/ofid/ofu110

94. European Association for Study of Liver. EASL recommendations on treatment of hepatitis C 2015. J Hepatol (2015) 63:199-236. doi:10.1016/ j.jhep.2015.03.025

95. Heim MH, Bochud PY, George J. Host - hepatitis C viral interactions: the role of genetics. J Hepatol (2016) 65:S22-32. doi:10.1016/j.jhep.2016.07.037

96. Noureddin M, Wright EC, Alter HJ, Clark S, Thomas E, Chen R, et al. Association of IL28B genotype with fibrosis progression and clinical outcomes in patients with chronic hepatitis C: a longitudinal analysis. Hepatology (2013) 58:1548-57. doi:10.1002/hep.26506

97. Bruno S, Thompson AJ, Critelli R, Crosignani A, Rossi S, De Lisi S, et al. Interferon lambda-3 is not associated with clinical outcome in patients with $\mathrm{HCV}$-induced compensated cirrhosis: a long-term cohort study. Antiviral Res (2015) 113:27-32. doi:10.1016/j.antiviral.2014.11.002

98. Bochud PY, Bibert S, Kutalik Z, Patin E, Guergnon J, Nalpas B, et al. IL28B alleles associated with poor hepatitis $\mathrm{C}$ virus (HCV) clearance protect against inflammation and fibrosis in patients infected with non-1 HCV genotypes. Hepatology (2012) 55:384-94. doi:10.1002/hep.24678

99. Eslam M, Hashem AM, Leung R, Romero-Gomez M, Berg T, Dore GJ, et al. Interferon-lambda rs12979860 genotype and liver fibrosis in viral and 
non-viral chronic liver disease. Nat Commun (2015) 6:6422. doi:10.1038/ ncomms 7422

100. Fabris C, Falleti E, Cussigh A, Bitetto D, Fontanini E, Bignulin S, et al. IL-28B rs12979860 C/T allele distribution in patients with liver cirrhosis: role in the course of chronic viral hepatitis and the development of HCC. J Hepatol (2011) 54:716-22. doi:10.1016/j.jhep.2010.07.019

101. Chang KC, Tseng PL, Wu YY, Hung HC, Huang CM, Lu SN, et al. A polymorphism in interferon L3 is an independent risk factor for development of hepatocellular carcinoma after treatment of hepatitis $\mathrm{C}$ virus infection. Clin Gastroenterol Hepatol (2015) 13:1017-24. doi:10.1016/j.cgh.2014.10.035

102. Joshita S, Umemura T, Katsuyama Y, Ichikawa Y, Kimura T, Morita S, et al. Association of IL28B gene polymorphism with development of hepatocellular carcinoma in Japanese patients with chronic hepatitis $\mathrm{C}$ virus infection. Hum Immunol (2012) 73:298-300. doi:10.1016/j.humimm.2011.12.021
103. Hong M, Schwerk J, Lim C, Kell A, Jarret A, Pangallo J, et al. Interferon lambda 4 expression is suppressed by the host during viral infection. J Exp Med (2016) 213(12):2539-52. doi:10.1084/jem.20160437

Conflict of Interest Statement: The authors declare that the research was conducted in the absence of any commercial or financial relationships that could be construed as a potential conflict of interest.

Copyright (c) 2016 Boisvert and Shoukry. This is an open-access article distributed under the terms of the Creative Commons Attribution License (CC BY). The use, distribution or reproduction in other forums is permitted, provided the original author(s) or licensor are credited and that the original publication in this journal is cited, in accordance with accepted academic practice. No use, distribution or reproduction is permitted which does not comply with these terms. 